\title{
Urinary Hydrogen Peroxide and Renal Function Parameter of Type 2 Diabetes Mellitus Patients Consuming Metformin and Metformin-Sulfonylurea
}

\author{
Rani Sauriasari, Rizky Mutiara Mahani, Andisyah Putri Sekar, Azizahwati \\ Faculty of Pharmacy, Universitas Indonesia, Depok, INDONESIA.
}

\begin{abstract}
Objective: Diabetes is one of the primary causes of kidney failure. About $40 \%$ people with diabetes will get Chronic Kidney Disease (CKD). The previous study reported that oxidative stress played an important role in diabetic patients with kidney damage. However, the study did not take consideration for the therapeutic treatment of the patients. This study purpose to determine urinary hydrogen peroxide concentration as a biomarker of oxidative stress in type 2 diabetes patients consuming metformin and metformin-sulfonylurea and to know its correlation with estimated Glomerular Filtration Rate (eGFR) and Urine Albumin to Creatinine Ratio (UACR) as a parameter of the renal function. Methods: Blood and urine were collected from 114 type 2 diabetes outpatients in Pasar Minggu Community Health Center. The concentration of urinary hydrogen peroxide $\left(\mathrm{H}_{2} \mathrm{O}_{2}\right)$ was measured using Ferrous Ion Oxidation Xylenol Orange 1 (FOX-1) method and was normalized with urine creatinine measured with kinetic Jaffe method. The value of eGFR was calculated based on serum creatinine using Cockroft-gault, MDRD, dan CKD-EPI equation. Results: There were no significant difference in concentration of urinary $\mathrm{H}_{2} \mathrm{O}_{2}(p=0.228)$, eGFR (Cockroft-Gault $p=0.936$; MDRD $p=0.779$; dan CKD-EPI $p=0.671$ ), and UACR ( $p=0.838$ ) between the two groups of treatment. There was no correlation between urinary $\mathrm{H}_{2} \mathrm{O}_{2}$ with eGFR in all equations and between urinary $\mathrm{H}_{2} \mathrm{O}_{2}$ and UACR. In the other hand, moderate positive correlation showed in
\end{abstract}

analysis between urinary $\mathrm{H}_{2} \mathrm{O}_{2}$ and $\mathrm{UACR}$ in patients with albuminuria $(\mathrm{r}=0.457$; $\mathrm{p}=0.001$ ). Results of linear regression analysis showed that $\mathrm{H}_{2} \mathrm{O}_{2}$ was the most and the only significant factor for increased UACR, even after controlled by age, gender, IMT, systolic blood pressure, $\mathrm{HbA} 1 \mathrm{c}$, hypertension status, smoking habit, exercise habit, and medicine. Conclusion: There was no significant difference in concentration of urinary $\mathrm{H}_{2} \mathrm{O}_{2}$ in type 2 diabetes patients consuming metformin and metformin-sulfonylurea. Urinary presumably will increase significantly together with the present of albuminuria, so it can not be used in early detection of renal function in patients without albuminuria.

Key words: Metformin, Sulfonylurea, Diabetes Mellitus, Estimated Glomerular Filtration Rate, Urine Albumin to Creatinine Ratio, Urinary Hydrogen Peroxide.

Correspondence :

Rani Sauriasari

Faculty of Pharmacy, Universitas Indonesia, Depok, 16424, INDONESIA.

Phone no: +627270031

Email: rani@farmasi.ui.ac.id

DOI: 10.5530/jyp.2017.1s.2

\section{INTRODUCTION}

Indonesia has around 10 million people with diabetes, in which about $90 \%-95 \%$ of all diabetes patients are people with type 2 diabetes mellitus. ${ }^{1}$ It is predicted to reach the number of 16.3 million in $2040 .{ }^{1,2}$ Diabetes is one of the primary causes of kidney failure. About $40 \%$ people with diabetes will get chronic kidney disease (CKD). Oxidative stress is known to play an important role in the molecular mechanism of kidney damage in diabetes, as shown by identification of isoprostane $e^{3}$, advanced oxidation protein products (AOPP) ${ }^{4}$ as a marker of oxidative stress lead to renal ischemia reperfusion injury. ${ }^{5}$ It develops when a number of reactive oxygen species (ROS) and antioxidants are imbalance and enzyme system cannot change ROS to unreactive species. It is known nephropathy diabetic could be induced at least in 5 pathways: abnormal electron transport in mitochondria, polyol pathway, production of advanced glycation end products (AGEs), Protein kinase C (PKC) pathway, and hexosamine pathway. ${ }^{6}$ Continuous hyperglycemia induce overproduction of ROS and it can result in kidney cell apoptosis. ${ }^{7}$

$\mathrm{H}_{2} \mathrm{O}_{2}$ is one type of ROS that can be measured in urine. ${ }^{8}$ An in vitro study reported that $\mathrm{H}_{2} \mathrm{O}_{2}$ exposure significantly increased apoptosis and reduced kidney cell survival. ${ }^{9}$ Urinary $\mathrm{H}_{2} \mathrm{O}_{2}$ has been used as a marker of oxidative stress in cancer patients. ${ }^{6}$ It also can be used as a marker of oxidative stress in healthy people who have a variety of lifestyles such as smoking, alcohol drinking, and exercise. ${ }^{10}$ However, the role of $\mathrm{H}_{2} \mathrm{O}_{2}$ as oxidative stress marker induces kidney damage in diabetes is still unclear.

First line treatment of type 2 diabetes mellitus in Indonesia is a single/ monotherapy of oral antidiabetic. The widely used medicine in first line therapy is metformin. If the treatment fails to reach the target in 3 months, patients will be received a combination of two oral antidiabetic drugs. ${ }^{11}$ Tight glycemic control can reduce the development and progression of diabetic nephropathy. ${ }^{12}$ However, it remains unknown whether oral anti-diabetic consumed by type 2 diabetes patients in Indonesia can reduce the risk of oxidative stress and diabetic complication in the kidney.

Diabetic nephropathy is usually detected when patients have been entered the final stage. Therefore, it is necessary to do research to discover the early marker of diabetic nephropathy. This study aims to determine the difference of urinary $\mathrm{H}_{2} \mathrm{O}_{2}$ concentration in type 2 diabetic patients consuming metformin and metformin-sulfonylurea and to know its correlation with estimated Glomerular Filtration Rate (eGFR) and Urine Albumin to Creatinine Ratio (UACR) as a parameter of the renal function.

This is an open access article distributed under the terms of the Creative Commons Attribution-Non Commercial-ShareAlike 4.0 License, which allows others to remix, tweak, and build upon the work non-commercially, as long as the author is credited and the new creations are licensed under the identical terms. 


\section{METHODS}

\section{Subject}

Fifty subject consuming metformin and 64 subjects consuming metformin-sulfonylurea have been selected in this study. All of the study subjects consume the medicine for at least 4 months. The local ethical committee, Faculty of Medicine, Universitas Indonesia, Dr. Cipto Mangunkusumo Hospital (44/UN2.F1/ETIK/1/2016) approved this study and all patients had given informed consent before blood and urine sampling.

\section{Urine and Blood Collections}

Patients included in this study were in a stated of fasting when blood and urine were collected. Exclusion criteria were patient with hematuria and severe anemia. We interviewed the patients who come to Pasar Minggu Community Health Center to identified patients fulfilling the inclusion criteria. Then, we made an appointment to collect blood and urine sample. Urine collected from every participant as much as $30 \mathrm{ml}$ in a plastic pot. Urine samples were allowed to stand 2 hours until separate into two parts. The clear part was taken and put into several microtubes. Urine in the microtube stored at $-80^{\circ} \mathrm{C}$ until analyzed. Blood was taken by certified phlebotomist from an accredited laboratory as much as 10 $\mathrm{ml}$. Then, the samples were analyzed in the laboratory to measure creatinine serum and $\mathrm{HbAlc}$.

\section{Measurement of eGFR}

eGFR defined based on three formulation, Cockroft-Gault, The Modification of Diet in Renal Disease (MDRD) and The Chronic Kidney Disease Epidemiology Collaboration (CKD-EPI) as shown in Table 1.

\section{Measurement of urine creatinine}

Urine creatinine was measured using the Creatinine Colorimetric Detection kit (Catalog No.ADI-907-030A, Enzo Life Science, USA). The principle was based on Jaffe reaction. Creatinine in urine will react with the picric acid in alkali condition resulting orange color and measured at $490 \mathrm{~nm} .{ }^{13} \mathrm{~A}$ urine sample was diluted in 1:20 by deionized water. The diluted sample, standard, and blank $(50 \mu \mathrm{l})$ were pipetted to appropriate well. Then, $100 \mu \mathrm{l}$ of creatinine detection reagent (the saturated picric acid and $\mathrm{NaOH} 1 \mathrm{~N}$ ) was added to the well. Sample and reagent were incubated for 30 minutes at room temperature. Then, absorbance was measured at $490 \mathrm{~nm}$. The calibration curve for measurement urine creatinine is prepared from creatinine standard at concentration of 20,10 , $5,2.5,1.25,0.625,0.3125 \mathrm{mg} / \mathrm{dL}$.

\section{Measurement of urine albumin}

Urine albumin was measured using the BCG Albumin Kit (Catalog No. MAK124-1KT, SIGMA). Standard albumin solution was made to 5.0, $4.0,3.0,2.0,1.5,1.0$, and $0.5 \mathrm{~g} / \mathrm{dL}$. The assay performed in duplicate. Five $\mu$ blank, standard, and sample solution were put into each well. Bromocresol Green (BCG) was then added into the well. The plate was incubated for 5 minutes, and the absorbance was measured at $\lambda 620 \mathrm{~nm}$.

\section{Measurement of urinary $\mathrm{H}_{2} \mathrm{O}_{2}$}

$\mathrm{H}_{2} \mathrm{O}_{2}$ is a marker of oxidative stress and contained in urine that can be measured. $\mathrm{H}_{2} \mathrm{O}_{2}$ measurement in the urine was conducted by FOX assay. The principle of this method is the oxidation of $\mathrm{Fe}^{2}+$ to $\mathrm{Fe}^{3}+$ by oxidizing agents in the samples, binding with Xylenol Orange (XO) and made a complex color that can be measured at $560 \mathrm{~nm}$. The complex color of $\mathrm{Fe}^{3}+-\mathrm{XO}$ is very sensitive to $\mathrm{pH}$ and optimum $\mathrm{pH}$ for performing this method is 1.7 to 1.8. FOX is not a specific method for the measure of $\mathrm{H}_{2} \mathrm{O}_{2}$. Other oxidizing agents also can oxidize $\mathrm{Fe}^{2+}$ into $\mathrm{Fe}^{3+}$. Therefore, this method is modified with the presence of catalase enzyme. Urinary hydrogen peroxide was measured by calculating the absorbance difference in the sample with catalase enzyme and on samples without catalase, in which catalase will selectively destroy $\mathrm{H}_{2} \mathrm{O}_{2}{ }^{7}$ The calibration curve for measurement hydrogen peroxide is prepared from $30 \% \mathrm{H}_{2} \mathrm{O}_{2}$ standard at a concentration of $50,25,12.5,6.25,3.125$, and $1.5625 \mathrm{mg} / \mathrm{dL}$.

\section{Statistical Analyses}

All data are expressed as sum (percentages) or mean \pm standar deviation or standard error of the mean. Independent t-test was applied in parametric data to compare the two treatments. Meanwhile, Mann-Whitney test was used for non-parametric data. Differences were considered significant at $\mathrm{p}<0.05$. Correlation between two variables was analyzed using bivariate test (person or spearman test). Linear regression analysis with stepwise method also conducted to know the most predictive factor for UACR. The results were significantly correlated if $\mathrm{p}<0.05$.

\section{RESULTS AND DISCUSSION}

\section{Calibration and linear regression analysis of urinary creatinine}

Linear regression analysis showed a very good and significant coefficient of determination in both groups. The coefficient of determination for metformin group was 0.9998 with the equation of $y=0.0879 x+0.012$. Meanwhile, the coefficient of determination for combination group was 0.9997 with an equation of $y=0.0859 x+0.014$.

Calibration and linear regression analysis of urinary hydrogen peroxide Linear regression analysis showed a very good and significant coefficient of determination $(r=0.9992)$ with linear equation $y=0.005 x+0.0097)$.

\section{Calibration and linear regression analysis of albumin}

Linear regression analysis showed a very good and significant coefficient of determination in both groups. The coefficient of determination for metformin group was 0.9995 with an equation of $y=0.1972 x+0.0087$. Meanwhile, a coefficient of determination for combination group was 0.9991 with an equation of $y=0.1958 x+0.0083$.

\section{Subject characteristics}

Complete data were obtained from 114 patients consist of 50 people ( 9 men, 41 women) consuming metformin and 64 people ( 10 men, 54 women) consuming a combination of metformin-sulfonylurea. Table 2 shows the basic characteristic of a study subject. Most of the study subjects in both groups were elderly. However blood pressure of most participants still under control. The urinary creatinine and serum creatinine in the two treatment groups were still in normal range, which indicating that most of the participants in this study have an apparently normal renal function. Effective antihypertensive treatment, such as angiotensin Iconverting enzyme inhibitors or angiotensin receptor blocker in patients can postpone or prevent diabetic nephropathy. ${ }^{14}$

Subject who consuming metformin-sulfonylurea has higher $\mathrm{HbA} 1_{\mathrm{C}}$ than metformin group, however, no significant difference between the two groups $(\mathrm{p}=0.066)$ statistically (Table 3 ). The mean of systolic and diastolic blood pressure of two groups was still in the normal ranges (124.80 $\pm 17.46 ; 126.56 \pm 16.26$ and $78.00 \pm 8.08 ; 78.44 \pm 7.39$ ). The mean UACR in the combination group was higher than in metformin group, even not statistically significant due to the nature of wide variation of individual concentration.

Mean of urinary $\mathrm{H}_{2} \mathrm{O}_{2}$ in the whole subjects is $80.80 \pm 11.02 \mu \mathrm{mol} / \mathrm{g}$ creatinine, whereas mean $\mathrm{H}_{2} \mathrm{O}_{2}$ level in healthy people as reported was 5.66 $\pm 8.27 \mu \mathrm{mol} / \mathrm{g}$ creatinine with the same analytical methods. ${ }^{10}$ Thus, the 
average concentration of urinary $\mathrm{H}_{2} \mathrm{O}_{2}$ in this study subjects was much higher than normal subjects. The level of urinary $\mathrm{H} 2 \mathrm{O} 2$ between the two groups also does not have a significant difference $(\mathrm{p}=0.228)$. Urinary $\mathrm{H}_{2} \mathrm{O}_{2}$, eGFR, and UACR were non-parametric, so we used Spearman correlation to determine the correlation between them. Analysis of correlation between urinary $\mathrm{H}_{2} \mathrm{O}_{2}$ and eGFR showed that there was no correlation between urinary $\mathrm{H}_{2} \mathrm{O}_{2}$ with eGFR and UACR. However, there was a moderate correlation between urinary $\mathrm{H}_{2} \mathrm{O}_{2}$ and UACR in albuminuria patients $(\mathrm{r}=0.457 ; \mathrm{p}=0.001)$ (Figure 1).

The linear regression analysis results indicate that hydrogen peroxide was the most predictive factor for UACR, even after controlled by age, gender, IMT, systolic blood pressure, HbA1c, hypertension status, smoking habit, exercise habit and medicine (Table 4).

Some study reported that urinary $\mathrm{H}_{2} \mathrm{O}_{2}$ level was influenced by coffee drinking. ${ }^{15}$ To avoid the bias effect of drink and foods, patients were fasting at least 8 hours before taking their urine and blood. The concentration of urinary $\mathrm{H}_{2} \mathrm{O}_{2}$ in both groups were not a significant difference. It's showed that there was no different effect to prevent oxidative stress between metformin and combination of metformin-sulfonylurea therapy. This result was similar to the previous study which found not significantly affect between metformin and sulfonylurea in all-cause mortality in type 2 diabetic patients. ${ }^{16}$

Mean of urinary $\mathrm{H}_{2} \mathrm{O}_{2}$ in the metformin group $(19.35 \pm 2.38)$ and in the metformin-sulfonylurea group $(23.18 \pm 1.83)$ were higher than the concentration in healthy people $(0.4$ to $5.71 \mu \mathrm{M})$ as reported previously

\section{Table 1: Formula of eGFR}

\begin{tabular}{|c|c|}
\hline Equation & eGFR (mL/minutes/1,73 m2) \\
\hline Cockroft-Gault & $\begin{array}{c}((140 \text { - age (years) }) \text { (Body Weight })(0.85 \text { for } \\
\text { female) }) /(\text { SCr x } 72)\end{array}$ \\
\hline \multirow[t]{2}{*}{$\begin{array}{l}\text { Modification of Diet in Renal } \\
\text { Disease (MDRD) }\end{array}$} & $186 \times(\mathrm{sCr}(\mathrm{mg} / \mathrm{dL}))^{-1.154} \times$ age $(\text { years })^{-0.203}$ \\
\hline & $\times 0.742$ (female) \\
\hline \multirow[t]{8}{*}{ CKD-EPI } & Female with $\mathrm{SCr} \leq 0.7$ \\
\hline & $(\mathrm{SCr} / 0.7)^{-0.329} \times 0.993^{\mathrm{age}} \times 144$ \\
\hline & Female with Scr $>0.7$ \\
\hline & $(\mathrm{SCr} / 0.7)^{-1.209} \times 0.993^{\text {age }} \times 144$ \\
\hline & Male with Scr $\leq 0.9$ \\
\hline & $(\mathrm{SCr} / 0.7)^{-1.209} \times 0.993^{\text {usia }} \times 144$ \\
\hline & Male with Scr $>0.9$ \\
\hline & $(\mathrm{SCr} / 0.9)^{-1.209} \times 0.993^{\mathrm{age}} \times 141$ \\
\hline
\end{tabular}

Table 2: Basic subject characteristics

\begin{tabular}{ccc}
\hline Variables & Metformin & $\begin{array}{c}\text { Metformin- } \\
\text { sulfonylurea }\end{array}$ \\
\hline Male & $9(18)$ & $10(16)$ \\
Female & $41(82)$ & $54(84)$ \\
Age (years) & $59.90 \pm 7.24$ & $58.81 \pm 7.26$ \\
Body weight (kg) & $61.12 \pm 10.66$ & $59.10 \pm 8.49$ \\
Body height (cm) & $152.06 \pm 6.30$ & $151.51 \pm 6.48$ \\
Body Mass Index (BMI) (kg/ & $26.36 \pm 3.93$ & $25.77 \pm 3.63$ \\
m2) & & \\
Duration of diabetes mellitus \\
$\quad$ (years)
\end{tabular}

which analyzed with the same analytical methods. ${ }^{10}$ Urinary hydrogen peroxide levels standardized by urine creatinine value $(53.62 \pm 13.84$ $\mu \mathrm{mol} / \mathrm{g}$ creatinine) still higher when compared to healthy subjects (5.66 $\pm 8,27 \mu \mathrm{mol} / \mathrm{g}$ creatinine).${ }^{10}$ Bivariate analysis between urinary $\mathrm{H}_{2} \mathrm{O}_{2}$ and eGFR showed that there was no correlation between them. This result is presumably caused by wide variation of intra-individual urinary $\mathrm{H}_{2} \mathrm{O}_{2}$. Yuen \& Benzie (2003) investigated urinary $\mathrm{H}_{2} \mathrm{O}_{2}$ as a potential biomarker of oxidative stress. They found that large biological variation can limit the usefulness of urine $\mathrm{H}_{2} \mathrm{O}_{2}$ even when concentration corrected by creatinine. ${ }^{17}$

High concentration of urinary $\mathrm{H}_{2} \mathrm{O}_{2}$ in diabetic patients causes by the interaction between RAS and ROS which related to renal dysfunction. Angiotensin-II-induced increases in $\mathrm{H}_{2} \mathrm{O}_{2}$ production in the renal medulla. Renal medullary NF- $\kappa \mathrm{B}$ activation also has positively correlated with local $\mathrm{H}_{2} \mathrm{O}_{2}$ production in the kidney. ${ }^{18}$ Patina et al (2014) also reported that $\mathrm{H}_{2} \mathrm{O}_{2}$ is oxidative stress biomarker which increased in diabetic rats renal medulla. ${ }^{19}$

Up to now, glomerular hyperfiltration leading to microalbuminuria is the earliest clinical marker of renal disease, which will progress into a renal damage, thus develop microalbuminuria and reduced glomerular filtration rate. ${ }^{14}$ This study showed that urinary $\mathrm{H}_{2} \mathrm{O}_{2}$ and UACR as the parameter of albuminuria has no correlation in total samples. In the other hand, moderate positive correlation showed in analysis between urinary $\mathrm{H}_{2} \mathrm{O}_{2}$ and UACR in patients with albuminuria (Figure. 1). Urinary hydrogen peroxide presumably will increase significantly together

Table 3: Clinical characteristic of study subjects

\begin{tabular}{cccc}
\hline Variables & $\begin{array}{c}\text { Metformin } \\
(\mathbf{n}=50)\end{array}$ & $\begin{array}{c}\text { Metformin- } \\
\text { sulfonylurea } \\
(\mathbf{n}=64)\end{array}$ & $\mathbf{p}$ \\
\hline HbA1C $(\%)$ & $8.58 \pm 1.77$ & $10.73 \pm 12.71$ & 0.803 \\
Systole $(\mathrm{mmHg})$ & $124.80 \pm 17.29$ & $126.56 \pm 16.26$ & 0.612 \\
Diastole $(\mathrm{mmHg})$ & $78.00 \pm 8.08$ & $78.44 \pm 7.39$ & 0.749 \\
Urine creatinine $(\mathrm{mg} / \mathrm{mL})$ & $0.10 \pm 0.06$ & $0.09 \pm 0.06$ & 0.173 \\
Serum creatinine $(\mathrm{mg} / \mathrm{dL})$ & $0.85 \pm 0.41$ & $0.83 \pm 0.49$ & 0.648 \\
$\mathrm{H}_{2} \mathrm{O}_{2}(\mu \mathrm{M})$ & $19.35 \pm 2.38$ & $23.18 \pm 1.83$ & 0.065 \\
$\mathrm{H}_{2} \mathrm{O}_{2}(\mu \mathrm{mol} / \mathrm{g} \mathrm{creatinine})$ & $68.19 \pm 14.14$ & $90.96 \pm 16.31$ & 0.228 \\
eGFR (ml/min/1.73 m2) & & & \\
Cockroft-Gault & $93.14 \pm 5.8$ & $93.75 \pm 4.92$ & 0.936 \\
MDRD & $95.86 \pm 5.94$ & $97.77 \pm 5.30$ & 0.779 \\
CKD-EPI & $84.18 \pm 3.78$ & $86.14 \pm 3.25$ & 0.671 \\
Albumin $(\mathrm{mg} / \mathrm{dL})$ & $24.71 \pm 6.22$ & $90.21 \pm 34.13$ & 0.696 \\
UACR $(\mathrm{mg} / \mathrm{g})$ & $326.49 \pm 112.19$ & $1893.54 \pm 536.96$ & 0.838 \\
\hline
\end{tabular}

Table 4: Linear Regression Analysis for UACR Using Stepwise Method

\begin{tabular}{ccc}
\hline Variables & Beta & $\mathbf{p}$ \\
\hline (standardized coefficients) & \\
\hline $\mathrm{H}_{2} \mathrm{O}_{2}(\mu \mathrm{mol} / \mathrm{g}$ creatinine) & 0.376 & $<0.001^{*}$ \\
\hline
\end{tabular}

UACR, Urine Albumin to Creatinine Ratio ${ }^{*} \mathrm{p}<0.05$, significant; adjusted by age, gender, BMI, systolic blood pressure, HbAlc, hypertension status, smoking habit, exercise habit and medicine 


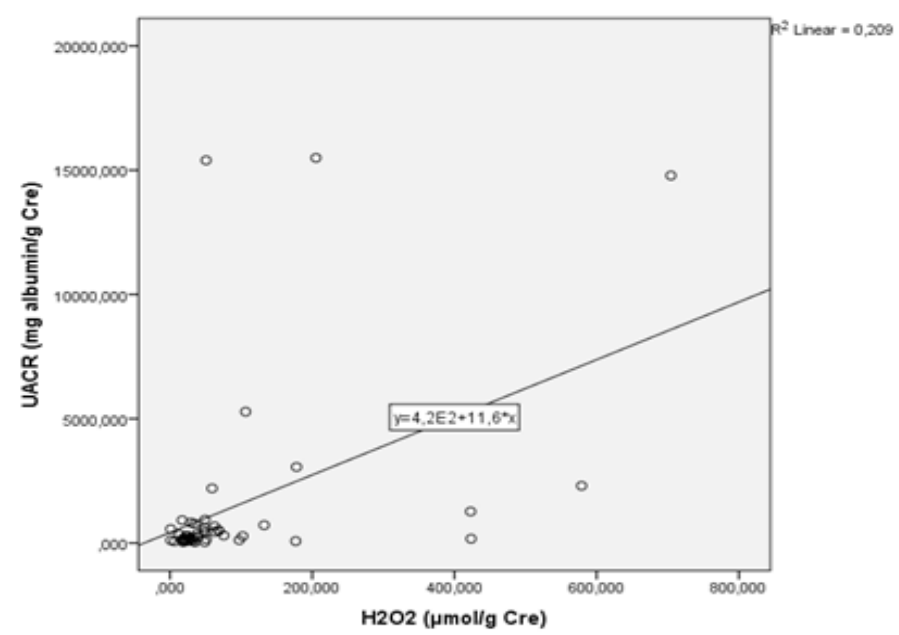

Figure 1: Correlation between urinary $\mathrm{H}_{2} \mathrm{O}_{2}$ and UACR on albuminuria patients

with the present of albuminuria, so it can not be used in early detection of renal function in patients without albuminuria.

This study has limitations such as the relatively small number of sample that can not represent the real condition. Nature unstable of $\mathrm{H}_{2} \mathrm{O}_{2}$ in urine may affect this study due to the sample trip from a place of sampling and analysis. However, we tried to minimize the degradation of $\mathrm{H}_{2} \mathrm{O}_{2}$ by maintaining the temperature with dry ice in a cool box. However, the advantages of this study are using a sample of patients with type 2 diabetes mellitus who fasting before blood and urine samples were taken.

\section{Standard protocol on approvals, registration, \& patient consents}

This study has been registered in Ethics Committee, Faculty of Medicine, Universitas Indonesia-Dr. Cipto Mangunkusumo Hospital (No.44/UN2. F1/ETIK/I/2016). Clinical examinations were undertaken using questionnaire and informed consent was given to subjects before sampling

\section{CONCLUSION}

In conclusion, there were no significant difference in concentration of urinary $\mathrm{H}_{2} \mathrm{O}_{2}$ in type 2 diabetes patients consuming metformin and metformin-sulfonylurea. Urinary $\mathrm{H}_{2} \mathrm{O}_{2}$ presumably will increase significant together with the present of albuminuria, so it can not be used in early detection of renal function in patients without albuminuria.

\section{CONFLICT OF INTEREST}

The authors declare that they have no conflict of interest.

\section{ACKNOWLEDGEMENT}

This study was supported by PUPT Grant, Ministry of Research and Higher Education, Indonesia. We also would like to thanks to DRPM (Directorate of Research and Community Engagement) Universitas Indonesia for the financial support and for their assistance.

\section{ABBREVIATIONS USED}

CKD: Chronic Kidney Disease; AOPP: Advanced Oxidation Protein Products; ROS: Reactive Oxygen Species; AGEs: Advanced Glycation End Products; PKC : Protein Kinase C; eGFR: estimated Glomerular Filtration Rate; MDRD: The Modification of Diet in Renal Disease; UACR:
Urine Albumin to Creatinine Ratio; CKD-EPI: The Chronic Kidney Disease Epidemiology Collaboration; BCG: Bromocresol Green; XO: Xylenol Orange; RAS: The Renin-Angiotensin System.

\section{REFERENCES}

1. National Kidney Foundation; The National Kidney Foundation. Glomerular Filtration Rate (GFR), 2015. New York (The United States of America): NKF; 2016.

2. Muchid A, Umar F, Ginting MN, Basri C, Wahyuni R, Helmi R, et al. Pharmaceutical care for diabetes mellitus. Community Pharmacy and Clinical Pharmacy Directorate, Ministry of Health, Republic of Indonesia. 2005. http://binfar.kemkes. go.id/?wpdmact=process\&did=MTc2LmhvdGxpbms=

3. Sauriasari R, Andrajati R, Azizahwati, Dharmeizar, Saputri DA, Muris RU, Manfaatun A, Amanda OF, Setiawan H, Sakano N. Wang DH, Ogino K. Marker of lipid peroxidation related to diabetic nephropathy in Indonesian type 2 diabetes mellitus patients. Diabetes Res Clin Pract. 2015;108(1):193-200. https://doi. org/10.1016/j.diabres.2014.12.016 ; PMid:25726335.

4. Mohammedi K, Patente TA, Bellili-Mu-oz N, Driss F, Le Nagard H, Fumeron F, Roussel R, Hadjadj S, Corrêa-Giannella ML, Marre M, Velho G. Glutathione peroxidase 1 (GPX1) variants, oxidative stress markers, and risk of kidney complications in patients with type 1 diabetes. Metabolism. 2016;65(2):12-9. https:// doi.org/10.1016/j.metabol.2015.10.004; PMid:26773925

5. Vaghasiya J, Sheth N1, Bhalodia Y, Jivani N. Diabetes Type-II Exaggerates Renal Ischemia Reperfusion Injury by Elevation of Oxidative Stress and Inflammatory Response. J Young Pharm. 2009;1(2):151-9. https://doi.org/10.4103/09751483.55748

6. Banerjee D, Madhusoodanan UK, Nayak S, Jacob J. Urinary hydrogen peroxide: a probable marker of oxidative stress in malignancy. Clin Chim Acta. 2003;334(1):205-9. https://doi.org/10.1016/S0009-8981(03)00236-5.

7. Small DM, Coombes JS, Bennett N, Johnson DW, Gobe GC. Oxidative stress, anti-oxidant therapies and chronic kidney disease. Nephrology. 2012;17(4):311 21. https://doi.org/10.1111/j.1440-1797.2012.01572.x; PMid:22288610.

8. Banerjee D, Jacob J, Kunjamma G, Madhusoodanan UK, Ghosh S. Measurement of urinary hydrogen peroxide by FOX-1 method in conjunction with catalase in diabetes mellitus--a sensitive and specific approach. Clin Chim Acta. 2004;350(1-2):233-6. https://doi.org/10.1016/j.cccn.2004.07.026 PMid:15530483.

9. Shahzad M, Small DM, Morais C, Wojcikowski K, Shabbir A, Gobe GC. Protection against oxidative stress-induced apoptosis in kidney epithelium by Angelica and Astragalus. J Ethnopharmacol. 2015;179:412-9. https://doi.org/10.1016/j. jep.2015.12.027; PMid:26719285.

10. Sato Y, Ogino K, Sakano N, Wang DH, Yoshida J, Akazawa Y, Kanbara S, Inoue K, Kubo M, Takahashi $\mathrm{H}$. Evaluation of urinary hydrogen peroxide as an oxidative stress biomarker in a healthy Japanese population. Free Radic Res. 2013;81(86). https://doi.org/10.3109/10715762.2012.759218.

11. Rudianto AD. Consensus of Management and Prevention of Type 2 Diabetes Mellitus in Indonesia. 2011;1-58.

12. Fioretto P, Bruseghin M, Berto I, Gallina P, Manzato E, Mussap M. Renal protection in diabetes: role of glycemic control. Clin J Am Soc Nephrol. 2006;17(4 suppl 2) :S86-9. https://doi.org/10.1681/ASN.2005121343; PMid:16565255.

13. Ohira SI, Kirk AB, Dasgupta PK. Automated measurement of urinary creatinine by multichannel kinetic spectrophotometry. Anal Biochem. 2009:384(2):238-44 https://doi.org/10.1016/j.ab.2008.10.015; PMid:18977332.

14. Rambhade SK, Singh S, Goswami RB, Rambhade A. Occurrence, complications, and interventions of diabetes: A new understanding of an old problem. Sys Rev Pharm. 2011;2(1):8-18. https://doi.org/10.4103/0975-8453.83433.

15. Hiramoto K, Kida T, Kikugawa K. Increased urinary hydrogen peroxide levels caused by coffee drinking. Biol Pharm Bull 2002;25(11):1467-71. https://doi org/10.1248/bpb.25.1467; PMid:12419961.

16. Hemmingsen B, Schroll JB, Wetterslev J, Gluud C. Sulfonylurea versus metformin monotherapy in patients with type 2 diabetes: a Cochrane systematic review and meta-analysis of randomized clinical trials and trial sequentia analysis. CMAJ. 2014;2(3):E162-75. https://doi.org/10.9778/cmajo.20130073; PMid:25295236 PMCid:PMC4185978.

17. Yuen JWM, Benzie IFF. Hydrogen Peroxide in urine as a potential biomarker of whole body oxidative stress. Free Radic Res. 2003;37(11):1209-13; https://doi. org/10.1080/10715760310001616032.

18. Kobori $\mathrm{H}$, Harrison-Bernard LM, Navar LG. Urinary excretion of angiotensinogen reflects intrarenal angiotensinogen production. Kidney Int. 2002;61 (2):57985. https://doi.org/10.1046/j.1523-1755.2002.00155.x; PMid:11849399 PMCid:PMC2575665

19. Patinha D, Afonso J, Sousa T, Morato M, Albino-Teixeira A. Diabetes-induced increase of renal medullary hydrogen peroxide and urinary angiotensinogen is similar in normotensive and hypertensive rats. Life Sci. 2014;108(2):71-9. https://doi.org/10.1016/j.Ifs.2014.05.011; PMid:24862547. 